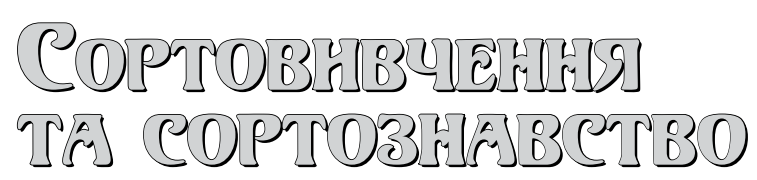

\title{
Growth, fruiting peculiarities and efficiency of cultivation of Ukrainian apple clones (Malus domestica Borkh.) of the 'Jonagold' variety
}

\author{
T. Ye. Kondratenko ${ }^{1}$, K. P. Tarnavska ${ }^{2}$ \\ ${ }^{1}$ National University of Life and Environmental Sciences of Ukraine, 15 Heroiv Oborony St., Kyiv, 03041, Ukraine, \\ e-mail: hortdep@gmail.com \\ 2Podillia Research Station of Horticulture of the Institute of Horticulture, NAAS of Ukraine, 1 Naukova St., Vedmezhe Vushko, \\ Vinnytsia district, Vinnytsia region, 23226, Ukraine, e-mail: ktarn1235@ukr.net
}

Purpose. On the basis of a comprehensive study of the characteristics of growth, development, fruiting and quality of the fruits of spontaneous mutants of the apple tree (Malus domestica Borkh.) of 'Jonagold' variety, select clones which differ from the original variety in tree growth strength and are superior in yield, marketability, fruit keeping quality and economic production efficiency of the latter. Methods. Field, laboratory, comparison, generalization and mathematical statistics. Results. The results of studying the growth and fruiting characteristics of 20 Ukrainian spontaneous clones of 'Jonagold' variety in the conditions of the Western Forest-Steppe of Ukraine are presented. It is revealed that plants of the studied clones did not differ in terms of beginning and duration of the main phenological phases and vegetation period from the varieties widely distributed and well adapted to Podillia conditions. The harvesting ripeness of the clone fruits came in the second or third decades of September with a difference of seven days. Trees of most clones (DP-4, DP-5, DP-9, DP-10, DP-13, DP-14 and DP-17) were medium-growing. The yield of five to eight-year-old clone plantations was 12.1-32.3 t/ha, which provided cost-effective cultivation in the conditions of Podillia, the level of production profitability was $66-242 \%$. All spontaneous mutants formed fruits larger than average size (except for DP-20, forming large ones), which are beautiful, elegant and vary in the intensity and character of the skin color depending on the clone. The clones DP-1, DP-3, DP-17, DP-18 and DP-19 were distinguished by a high yield of fruits of the highest and first grade. The clones DP-1, DP-3, DP-17, DP-18 and DP-19 were marked by the highest yield of apples of the higher and the first commodity grade, and this property was significantly superior to the yield of the control variety. The tested clones are divided into three groups according to the fruit ripening dates: early winter, winter, and late winter. Conclusions. A long-term assessment of the objects of study revealed that the biological properties Ukrainian clones of 'Jonagold' variety correspond to the climatic conditions of the Western Forest-Steppe of Ukraine. Most of them belong to the medium-growth group (DP-4, DP-5, DP-9, DP-10, DP-13, DP-14 and DP-17) and are characterized by a mixed type of fruiting. Clones DP-1, DP-3, DP-17, DP-18 and DP-19 were distinguished by a high yield of fruits of the highest and first commodity grade. According to the main indicators of fruit quality, clones DP-3, DP-8, DP-13, DP-14, DP-16, DP-17, DP-18 and DP-20 were recognized as the best; the highest economic efficiency of apple production in Podillia was provided by clones DP-14, DP-17, DP-18 and DP-19. The latter ones are recommended for registration in "The State Register of plant varieties suitable for dissemination in Ukraine", as promising clones for introduction into planting for the production of fruits of universal purpose in the zone of the Western Forest-Steppe of Ukraine.

Keywords: apple; variety; 'Jonagold'; clone; tree growth strength; fruiting type; fruit quality; keeping quality.

\section{Introduction}

'Jonagold', as a polyclonal apple variety, has long been popular abroad and in Ukraine because its apples are characterized by attractive appearance, excellent taste and universal

Tetyana Kondratenko

https://orcid.org/0000-0003-0519-568X

Kateryna Tarnavska

https://orcid.org/0000-0003-4935-470X purpose [1-3]. During 1998-2010 researchers at the NAAS Institute of Horticulture and its research station network determined that among the wide diversity of new varieties of domestic and foreign breeding, 'Jonagold' is one of the best for laying out intensive gardens in the Forest-Steppe of Ukraine [4].

Due to the genetic instability of the variety, more than 200 of its clones have been selected in many countries. The most famous and common are clones 'Jonagored', 'Dekosta', 'Red 
Jonaprince', 'King Jonagold' discovered in Belgium; 'Jonica', 'Rubinstar' - in Germany; 'Boerekamp Early Quee', 'Wilmuta' - the Netherlands [2, 5]. All these clones differ from the original variety by the best quality of fruits. Its formation is influenced by the biological characteristics of the plants, soil and climatic factors of the growing zone, meteorological conditions of the year, agricultural technology of cultivation (system of soil content, nutrition, irrigation, rootstock type, etc.) $[1,2,6]$. It is the influence of those factors that determines the formation of the commodity and nutritional properties of apples, and their suitability for long-term storage in varieties of winter ripening.

In the world apples of popular 'Jonagold' variety clones differ slightly in properties, which is due to a certain reaction to specific conditions of cultivation. The study of marketability and taste of 'Jonagold', 'Wilmuta', 'Dekosta' and 'Jonagored' fruits grown under the conditions of the Forest-Steppe of Ukraine, allowed A. I. Trokhimchuk [7] to make a conclusion about enhanced marketability of apples. They were characterized by a good shape, intense cover color, as well as medium ('Dekosta', 'Jonagored') and above average ('Wilmuta', 'Jonagold') mass of fruits. According to the results of tastings, fruits of the above varieties were considered attractive (8.2-8.5 points) and met taste preferences (8.3-8.5 points) of Ukrainian consumers. In the ForestSteppe and Crimea conditions, 'Jonagold' variety and its clones had the highest rating on a set of indicators that generally characterize the marketable qualities of fruits. Apples were above medium and large size, high dimensionality, attractiveness, and the output of marketed products was more than $90 \%$.

Apples that are suitable for long-term storage are sold in the winter-spring period at higher prices and provide the enterprise with the receipt of funds for a long time. Studies conducted by A. I. Trokhimchuk [7] showed that fruits of 'Wilmuta' (200 days), 'Jonagored' (195 days), 'Jonagold' (185 days) and 'Dekosta' (178 days) clones can be stored in the refrigerator for a long time. According to V. P. Ripamelnik [8], fruits of 'Jonagored' and 'Dekosta' clones were preserved for 143 days, 'Jonagold' - 189 days, and 'Boerekamp Early Queen' - 200 days. Apples of 'Jonagold' variety and its clones grown in the conditions of the Krasnodar Territory can maintain consumer qualities of fruits for up to 6 months [9].

It is well known that in compacted intensive plantings, the luminance of tree canopies is sufficient if the height of the trees does not exceed $3.5 \mathrm{~m}$, and the diameter of the crown is no more than $3 \mathrm{~m}$ [10]. According to T. E. Kondratenko [2], the trees of introduced clones do not differ significantly in growth strength and crown characteristics from the original 'Jonagold', which belongs to vigorous cultivars. Only in trees of 'Jonaprince' variety T. V. Bogdanovich [11] determined average strength of growth. Improvement of the economic and biological properties of this valuable variety in many countries is achieved by clone breeding. Most cultivated foreign clones are not adapted to the conditions of the Forest-Steppe and Polissia of Ukraine, therefore, clone breeding in industrial plantings of this variety in the Western Forest-Steppe in order to separate clones with improved economic and biological properties is relevant and promising for the most favorable for the apple tree area [12].

The aim of the research. Based on a comprehensive study of growth characteristics, development, fruiting and quality of the fruits of spontaneous mutants of the apple tree (Malus domestica Borkh.) of 'Jonagold' variety, select plants that differ from the original variety in tree growth strength and superior in yield, marketability, fruits keeping quality and economic efficiency of production of the latter.

\section{Materials and methods}

During 2012-2018 in the state apple trees variety testing plantings, which were laid in spring 2007 at the Podolsk experimental horticulture station of the Institute of Horticulture of the National Academy of Sciences of Ukraine (Podillia RSH of IH of the NAAS of Ukraine) (Vinnytsia district, Vinnytsia region), 20 spontaneous mutants (clones) of 'Jonagold' variety of Ukrainian breeding were studied. They were seperated during 20032006 in the industrial planting 'Jonagold' of the above station by scientific employees A. P. Dovbysh, A. A. Mukharskyi, A. Yu. Borodai.

One-year-old seedlings of 'Jonagold' variety clones, as well as 'Idared' (control), 'Jonagold' (conditional control) on the MM.10 rootstock were planted according to the $4.5 \times 1.5 \mathrm{~m}$ pattern. The crown of the trees was shaped like a slender spindle. Plants were non-irrigated. The research site soil was dark gray forest podzolic, sandy loam.

The laying and conducting of experiments, the main counts and observations were carried out according to the Method of the State Register of Plant Varieties, suitable for distribu- 
tion in Ukraine (fruit, berry, nut-bearing, subtropical, grapes and mulberry) [13] and the Program and method of varietal study of fruit, berry and nut-bearing crops [14].

The harvesting maturity of fruits was determined by Iodine Test for Starch, the pulp density was measured with an FT 327 penetrometer with a probe diameter of $11 \mathrm{~mm}$. The marketability of the fruits was evaluated according to the requirements of State standard GOST EEK 00H FFV-50: 2007 [15] and State standard GSTU 01.1-37-59 2004 [16].

Statistical analysis of the measurement results was carried out by the methods of B. A. Dospekhov [17] using the computer data processing program "AGROSTAT" $[18,14]$. Meteorological conditions were characterized according to the data of the Davis $6152 \mathrm{EU}$ weather station, located in the plantings of the apple tree at the Podillia RSH of IH of the NAAS of Ukraine.

The climate of the research region is temperate continental. The average long-term amount of precipitation is $595.4 \mathrm{~mm}$, of which about $70 \%$ occur during vegetation season. The average annual air temperature is $9.2{ }^{\circ} \mathrm{C}$. During the study period, the average annual precipitation was $591.8 \mathrm{~mm}$; the lowest $(395 \mathrm{~mm})$ was recorded in 2015 , the highest $(734 \mathrm{~mm})$ in 2013. The sum of active temperatures $\left(10{ }^{\circ} \mathrm{C}\right.$ and higher) ranged from $3091^{\circ} \mathrm{C}(2014)$ to $3317{ }^{\circ} \mathrm{C}(2015)$. Winter period $2011-2012$ was the coldest for the entire period of the study, the absolute minimum was $-30.2{ }^{\circ} \mathrm{C}$ (II decade of February 2012).

\section{Results and discussion}

Phenological observations showed that the plants of the spontaneous 'Jonagold' clones began to grow on $5.04 \pm 5$ days. One day later than the 'Jonagold' variety, the timing of this phase was noted for clones DP-4, DP-5, DP-6, DP-10, DP-12, DP-13, DP-14, DP-19 and DP-20.

'Jonagold' clones differed among themselves in terms of the beginning of flowering. 'Idared' trees (27.04 \pm 3$)$ (c.) and GP 12 (28.04 \pm 3 ) began to bloom first, DP-19 and DP-20 were the last ( $3 \pm 2$ days later than the original variety). Flowering of the trees of the remaining clones and the control variety 'Jonagold' took place on average time frame (30.04 \pm 2 ). Analysis of the data on the timing of the beginning of flowering revealed that $90 \%$ of the 'Jonagold' clones entered this phase at the end of the third decade of April with the sum of active temperatures $267 \pm 14{ }^{\circ} \mathrm{C}$.

All spontaneous clones had a long and very long flowering period. The first group inclu- ded DP-1, DP-6, DP-7, DP-13, DP-17, DP-19 and DP-20. The plants of the remaining clones and in control varieties 'Idared' and 'Jonagold' the longest flowering period $(12 \pm 2$ days) was recorded. Over the entire period of research, plants of domestic clones bloomed with an average intensity of 4.2-6.0 points. Moreover, DP-2 and DP-13 clones were characterized by the most generous flowering (6.0 points). The trees of the original 'Jonagold' variety bloomed by 6.9 points, and the control variety 'Idared' - by 6.6 points. Fruit setting on clone trees was $14-26 \%$ and was slightly different from 'Jonagold' and 'Idared'.

The growth of shoots during the entire period of the evaluation of the clones passed in a single wave; its end was observed during the first ten days of August (6.08 $\pm 6-10.08 \pm 6)$. Two waves of growth were noted only in 2014 , the end of the second one was in the first decade of October. In all studied clones, the period from the beginning of formation to the harvesting ripeness of the fruits was $126 \pm 1$ days with the sum of active temperatures $2729 \pm$ $116{ }^{\circ} \mathrm{C}$. Using Iodine Test for Starch, it was found that the harvesting ripeness of fruits of spontaneous clones occurred in the second and third decades of September with the difference between clones of 7 days (Fig. 1).

Apples of DP-4, DP-12 and DP-14 clones reached harvesting maturity first $(10.09 \pm 5)$, and DP-20 (22.09 \pm 5$)$ - the last; in the 'Jonagold' variety, this phase came on $13.09 \pm 4$. Thus, the harvesting maturity of fruits of the first group clones occurred at a lower sum of active temperatures than in 'Jonagold'. DP-20 apples completed the growth and accumulation of nutrients later than all the studied clones.

In the conditions of the Western ForestSteppe of Ukraine, the vegetation period of plants of all the studied clones and the control variety 'Jonagold' was $216 \pm 4-219 \pm 6$ days; the longest ( $222 \pm 7$ days) it was in the trees of control variety 'Idared'.

Under the same conditions of plant formation, pruning and growth restriction, the height difference of 'Jonagold' clone trees was significant. For the fourth year of growth in the garden, clones DP-5, DP-9, DP-13, DP-14 and DP-19 stood out for the lowest height of trees, DP-7, DP-8, DP-12 were the highest. At eight years of age, spontaneous clones DP-4, DP-5, DP-9, DP-10, DP-13, DP-14, DP-17 and the control variety 'Idared' (Table 1 ) were the smallest trees in height. In other clones, as in the control variety 'Jonagold', the height of the trees exceeded $4 \mathrm{~m}$. Clones DP-1, DP-9, DP-13, DP-14, DP-16, DP-19 and the control 

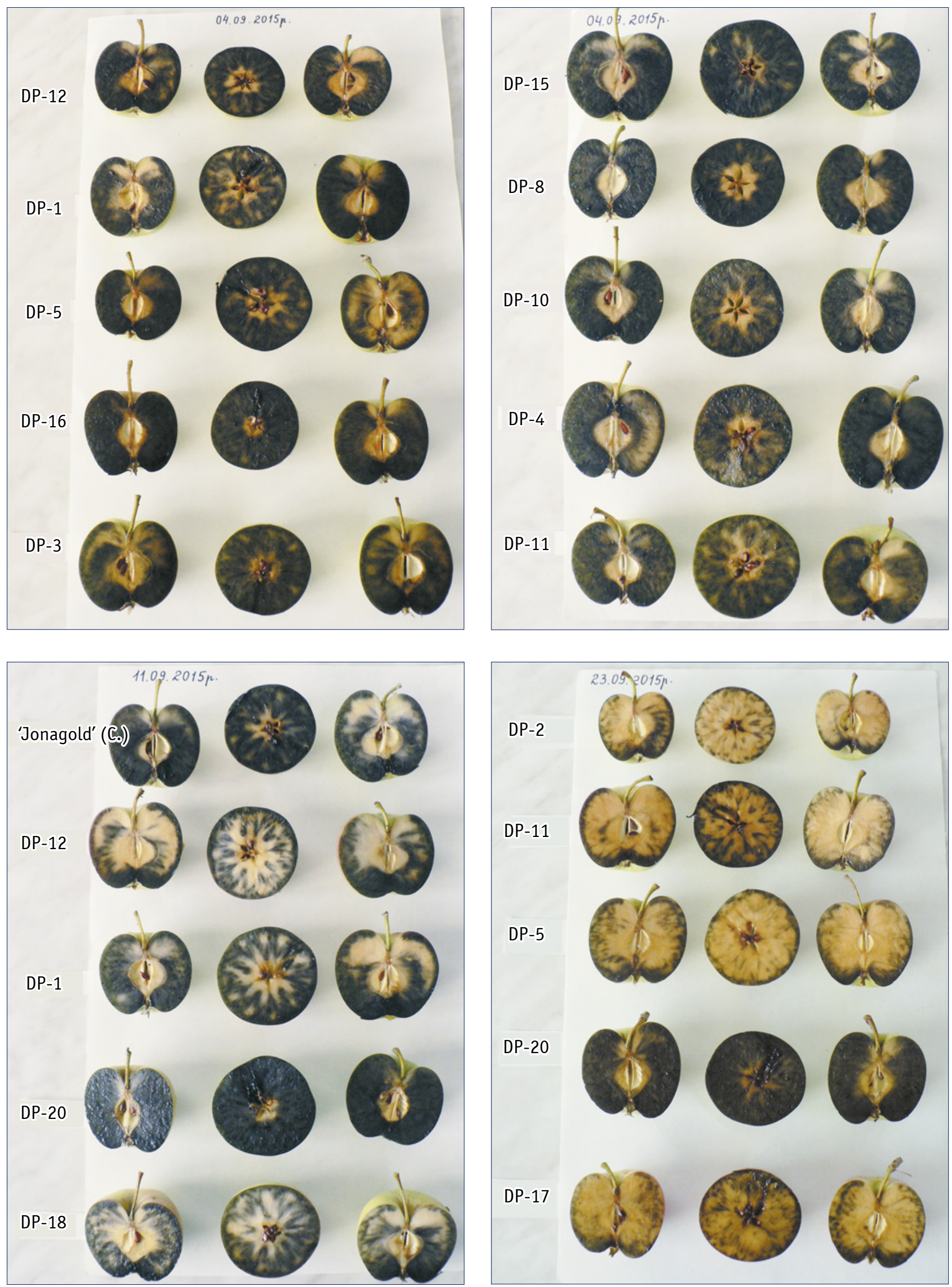

Fig. 1. The difference in the onset of harvesting maturity of the fruits of the 'Jonagold' clones and control varieties, determined using Iodine Test for Starch (04-23.09.2015) 
variety 'Jonagold' were characterized by intense growth of trees in height in the first four to eight years after the laying of the garden. According to the classification of trees according to size, clones DP-4, DP-5, DP-9, DP-10, DP-13, DP-14 and DP-17 belonged to the middle-grown. The rest of the studied clones and the original variety were strongly grown.

The smallest width of the crown at the age of four had the trees of clones DP-2, DP-5 and DP-20, and the largest - DP-1, DP-8, DP-12
(Table 1). During this period, the plants of all clones took control of the space allocated to them in a row according to the planting scheme. The diameter of the crown of eight-year-old spontaneous clone trees was $2.0-2.5 \mathrm{~m}$ (close to the level of control varieties) and $0.5-1.0 \mathrm{~m}$ greater than the distance allocated for trees. The maximum width of the crown during this period was characterized by plants of clones DP-3, DP-6, DP-12, DP-15, DP-17, and the most compact was in DP-10, DP-13 (at the level of the control variety 'Idared').

Parameters of four and eight-year-old trees of the 'Jonagold' clones under study (2007 planting, MM.10 rootstock, planting pattern $4.5 \times 1.5 \mathrm{~m}$ ) the Podillia RSH of IH of the NAAS of Ukraine

\begin{tabular}{|c|c|c|c|c|c|c|c|c|}
\hline \multirow{3}{*}{ Veriety, clone } & \multicolumn{2}{|c|}{ Height of trees, $m$} & \multicolumn{4}{|c|}{ Crown diameter, $\mathrm{m}$} & \multicolumn{2}{|c|}{$\begin{array}{c}\text { Cross-sectional area } \\
\text { of the stem, } \mathrm{cm}^{2}\end{array}$} \\
\hline & \multirow{2}{*}{4 y.o. } & \multirow{2}{*}{8 у.о. } & \multicolumn{2}{|c|}{ along row } & \multicolumn{2}{|c|}{ across row } & \multirow{2}{*}{2011} & \multirow{2}{*}{2015} \\
\hline & & & 2011 & 2015 & 2011 & 2015 & & \\
\hline ‘Idared’(c.) & 3.38 & 3.86 & 1.8 & 2.0 & 1.6 & 1.9 & 15.3 & 34.4 \\
\hline ‘Jonagold' (c. c.) & 3.74 & 4.70 & 2.0 & 2.3 & 1.8 & 2.4 & 23.5 & 42.5 \\
\hline DP-2 & 3.82 & 4.40 & 1.6 & 2.4 & 1.5 & 2.3 & 15.6 & 55.0 \\
\hline DP-4 & 3.70 & 3.80 & 1.9 & 2.2 & 1.6 & 2.1 & 16.7 & 40.7 \\
\hline DP-5 & 2.78 & 3.34 & 1.7 & 2.4 & 1.5 & 2.3 & 16.0 & 27.9 \\
\hline DP-6 & 3.68 & 4.08 & 1.9 & 2.6 & 1.8 & 2.4 & 21.8 & 50.0 \\
\hline DP-7 & 4.52 & 4.04 & 1.8 & 2.2 & 1.7 & 2.5 & 19.7 & 57.6 \\
\hline DP-8 & 4.14 & 4.16 & 2.1 & 2.3 & 1.8 & 2.7 & 21.9 & 56.1 \\
\hline DP-9 & 3.08 & 3.88 & 1.9 & 2.2 & 1.9 & 1.9 & 20.3 & 35.9 \\
\hline DP-10 & 3.92 & 3.91 & 1.8 & 2.1 & 1.7 & 2.3 & 19.0 & 58.7 \\
\hline DP-12 & 4.14 & 4.46 & 2.1 & 2.6 & 1.8 & 2.5 & 20.2 & 60.5 \\
\hline DP-13 & 2.98 & 3.96 & 1.9 & 1.9 & 1.6 & 2.4 & 18.2 & 23.1 \\
\hline DP-14 & 2.90 & 3.64 & 1.9 & 2.3 & 1.7 & 2.1 & 16.8 & 24.5 \\
\hline DP-15 & 4.00 & 4.16 & 1.9 & 2.5 & 1.8 & 2.1 & 23.5 & 58.7 \\
\hline DP-17 & 3.84 & 3.68 & 1.9 & 2.5 & 1.9 & 2.5 & 20.9 & 47.6 \\
\hline DP-18 & 3.38 & 4.02 & 1.9 & 2.3 & 1.7 & 2.1 & 24.1 & 42.6 \\
\hline DP-19 & 3.02 & 4.12 & 1.9 & 2.4 & 1.9 & 2.1 & 19.7 & 50.2 \\
\hline DP-20 & 3.88 & 4.14 & 1.7 & 2.3 & 1.6 & 2.5 & 24.1 & 64.1 \\
\hline $\mathrm{LSD}_{0.0}$ & 0.500 & 0.390 & 0.38 & 0.30 & 0.29 & 0.28 & $\mathrm{~F}_{\mathrm{f}}<\mathrm{F}_{05}$ & 3.76 \\
\hline
\end{tabular}

The growth rate of fruit trees is objectively characterized by the stem cross-sectional area (SCSA) [19, 20]. At the age of four, this indicator showed no significant difference between the plants of the original variety and the studied clones (Table 1). The eight-yearold trees of clones DP-5, DP-9, DP-13, DP-14 and the control variety 'Idared' had the smallest cross-sectional area of the stem; it was significantly higher in DP-1, DP-2, DP-3, DP-6, DP-7, DP-8, DP-10, DP-11, DP-12, DP-15, DP-16, DP-17, DP-19, DP-20. Intensive increase in the cross-sectional area of the stem over a period of four to eight years was characteristic for clones DP-3, DP-6, DP-16, DP-18, DP-19, DP-20, and the least intensive it was in DP-5, DP-9, DP-13 DP-14, DP-18 and the control varieties 'Idared' and 'Jonagold' (Table 1 ). So, according to a set of growth indica- tors, clones DP-4, DP-5, DP-9, DP-10, DP-13, DP-14 and DP-17 belong to the group of middle-grown. The remaining clones and control varieties were characterized by strong tree growth.

On the trees of the studied clones spurs $(59-72 \%)$ dominated among the fruit formations, spears accounted for $11-22 \%$, fruit twigs $-15-23 \%$. According to the classification of varieties by type of fruiting [21], all the studied clones belong to the third group; their trees were characterized by a mixed type of fruiting, as well as the control varieties.

Trees of the most clones, as well as the original variety, were characterized by average awakening of the buds. Only in DP-13 trees it was high. High shoot-forming ability is inherent in the trees of all clones, except for DP-12, DP-19 (medium) and DP-17 (weak). Plants of 
all studied clones had a rounded crown. Its density depended on the clone; trees of DP-1, DP-5, DP-7, DP-8, DP-9, DP-16, DP-17, DP-18 and DP-19 formed a thick crown, and the remaining clones had moderately thickened one.

Our studies have shown that the crowns of four-year-old trees take full control of the space determined by the planting scheme. Branches of eight-year trees of DP-1, DP-2, DP-3, DP-5, DP-6, DP-12, DP-15, DP-16, DP-17 and DP-19 clones reached $2.4-2.6 \mathrm{~m}$, that is, they went beyond the allocated distance in a row of 0.9-1.1 $\mathrm{m}$ and intertwined with each other. To keep their crowns within the $4.5 \times 1.5 \mathrm{~m}$ scheme (on the MM.106 rootstock), a strong pruning should be carried out annually. Since cultivation of such a garden requires at least 15 years, it will become increasingly difficult to keep the trees in the allocated space every year. Therefore, the layout of 'Jonagold' clone trees needs to be adjusted. In our opinion, it is advisable to consider $4.5 \times 2.0 \mathrm{~m}$ (1111 trees/ha) as the appropriate arrangement of trees of all clones on MM.106 rootstock instead of the initial $4.5 \times 1.5 \mathrm{~m}$.

The average yield of five to ten-year-old plantations of domestic clones on MM.106 rootstock was 12.2-22.2 t/ha (Table 2). The highest yield was reached by all spontaneous clones at the age of eight (21.7-32.3 t/ha) and ten (23.6-31.2 t/ha) years, except DP-20. In the eighth year of growth in the garden only trees of DP-1 clone had a significantly higher yield than 'Jonagold'. In the ten-year garden, the yield of clones was at the level of the original 'Jonagold' variety. The total yield (133.9$142.0 \mathrm{t} / \mathrm{ha}$ ) of clones DP-1, DP-18 and DP-19 was higher than that of 'Jonagold' (2011-2017).

The yield of 'Jonagold' clones (2007, planting, $4.5 \times 1.5 \mathrm{~m}$, MM.106 rootstock),

Table 2

Podillia RSH of IH of the NAAS of Ukraine, 2011-2017

\begin{tabular}{|l|c|c|c|c|c|c|c|c|}
\hline \multirow{2}{*}{\multicolumn{1}{|c|}{ Variety, clone }} & \multicolumn{7}{c|}{ Yield (t/ha) by years } \\
\cline { 2 - 8 } & 2011 & 2012 & 2013 & 2014 & 2015 & 2016 & 2017 & average during 2012-2017 \\
\hline 'Idared' (c.) & 11.9 & 22.1 & 22.8 & 10.7 & 19.9 & 23.0 & 21.3 & 20.0 \\
'Jonagold' (c. c.) & 10.6 & 17.2 & 25.8 & 9.3 & 20.6 & 11.4 & 28.6 & 18.8 \\
DP-1 & 10.4 & 26.4 & 16.2 & 10.5 & 32.3 & 11.6 & 26.5 & 20.6 \\
DP-2 & 8.0 & 13.0 & 14.1 & 4.9 & 23.5 & 8.0 & 27.5 & 15.2 \\
DP-3 & 10.1 & 20.1 & 19.5 & 7.2 & 28.2 & 7.0 & 26.4 & 18.1 \\
DP-4 & 10.2 & 20.9 & 14.4 & 12.1 & 24.9 & 14.9 & 25.1 & 18.7 \\
DP-5 & 12.1 & 15.6 & 14.2 & 8.1 & 21.9 & 10.6 & 28.1 & 16.4 \\
DP-6 & 11.0 & 21.6 & 21.8 & 7.6 & 23.4 & 9.0 & 24.6 & 18.0 \\
DP-7 & 11.3 & 20.5 & 18.6 & 7.8 & 22.8 & 13.8 & 31.2 & 19.1 \\
DP-8 & 16.9 & 18.0 & 10.7 & 6.2 & 25.4 & 8.7 & 30.8 & 16.6 \\
DP-13 & 9.7 & 16.8 & 16.1 & 9.8 & 24.1 & 12.7 & 25.0 & 17.4 \\
DP-15 & 10.3 & 21.6 & 20.2 & 5.6 & 29.5 & 11.4 & 25.4 & 19.0 \\
DP-17 & 9.1 & 21.5 & 20.0 & 11.1 & 27.4 & 8.9 & 28.0 & 19.5 \\
DP-19 & 8.5 & 23.1 & 19.9 & 8.4 & 29.7 & 22.7 & 29.7 & 22.2 \\
DP-20 & 8.3 & 12.1 & 8.1 & 2.2 & 16.8 & 21.2 & 12.9 & 12.2 \\
\hline \multicolumn{1}{|c|}{ LSD $_{0.05}$} & $\mathrm{~F}_{\mathrm{f}}<\mathrm{F}_{05}$ & $\mathrm{~F}_{\mathrm{f}}<\mathrm{F}_{05}$ & 9.37 & 8.29 & 9.24 & 7.04 & 9.69 & - \\
\hline
\end{tabular}

It was revealed that all clones formed fruits larger than the average size, except for DP-20 (large). In clones DP-2, DP-4, DP-5, DP-7, DP-9, DP-10, DP-11, DP-13, DP-14, apples did not differ significantly in weight from the original variety. In the remaining clones - DP-1, DP-3, DP-6, DP-8, DP-12, DP-15, DP-16, DP-17, DP-18, DP-19 and DP-20 they were large. Most spontaneous clones did not differ from each other in the transverse diameter of the fruit; the difference was within the experimental error. The exception was clones DP-1, DP-8, DP-15, DP-17 and DP-20; their apples were larger in diameter than those of the original cultivar.

Over the entire period of research, the trees of DP-1, DP-3, DP-17, DP-18 and DP-19 clones formed the largest number of apples of the highest and first grade $(41-55 \%)$, which significantly exceeds the control options. Most of the fruits of the second grade were found on plants of DP-2, DP-12, DP-15, DP-16 clones. The smallest number $(18-19 \%)$ of nonstandard fruits was noted on the trees of DP-17 and DP-15 clones, the largest $(37-39 \%)$ in DP-2, DP-7 and 'Idared' variety. Apples of all the studied clones were beautiful, medium and above average sizes, medium uniformity, regular shape with a smooth surface, covered with medium and small green subskin specks and brown spots [3]. However, the fruits were most attractive in DP-3, DP-8, DP-17, DP-18 and DP-20 clones due to the bright integument color (Figs. 2 and 3). The latter differed 
in the intensity and nature of the coat color. In apples of DP-3 and DP-8 clones were dark red, blurred blush covered $3 / 5$ of the surface, DP-18 almost the entire surface. The fruits of clone DP-17 were covered dark red, blurry dotted with a dash blush over the entire surface. DP-20 clone did not belong to any of the given groups, since its apples had only the main light green color; peel coloration was absent. For most clones, the nature of the peel coloration turned out to be a constant sign, and its intensity depended on the sum of active temperatures of $10{ }^{\circ} \mathrm{C}$ and higher, which developed over the period of harvesting ripeness of the fruits, as well as on the presence of significant (13.4-22.0 ${ }^{\circ} \mathrm{C}$ ) night differences and daily air temperatures in the last 2-3 weeks before harvesting.
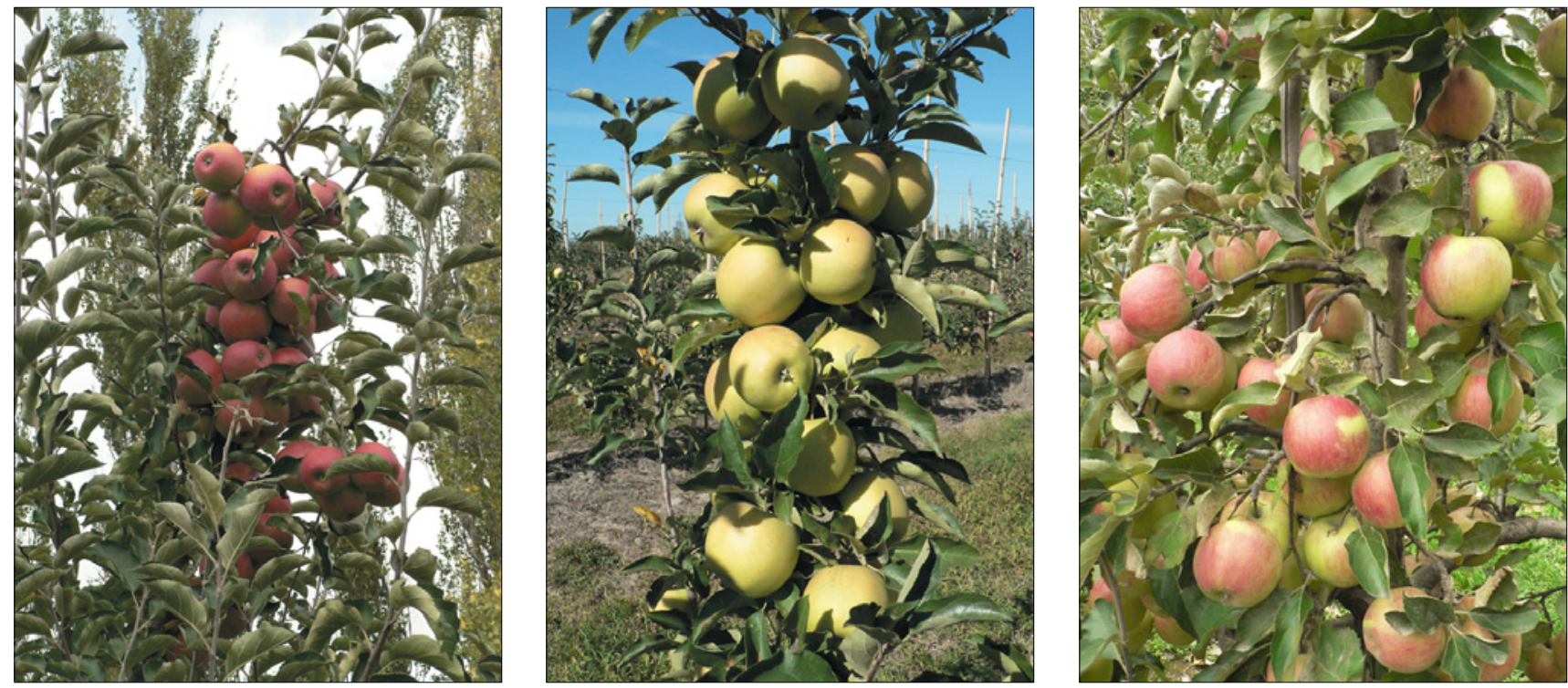

Fig. 2. Appearance of the fruits of clones DP-3, DP-20 and DP-9 (from left to right, 2015)
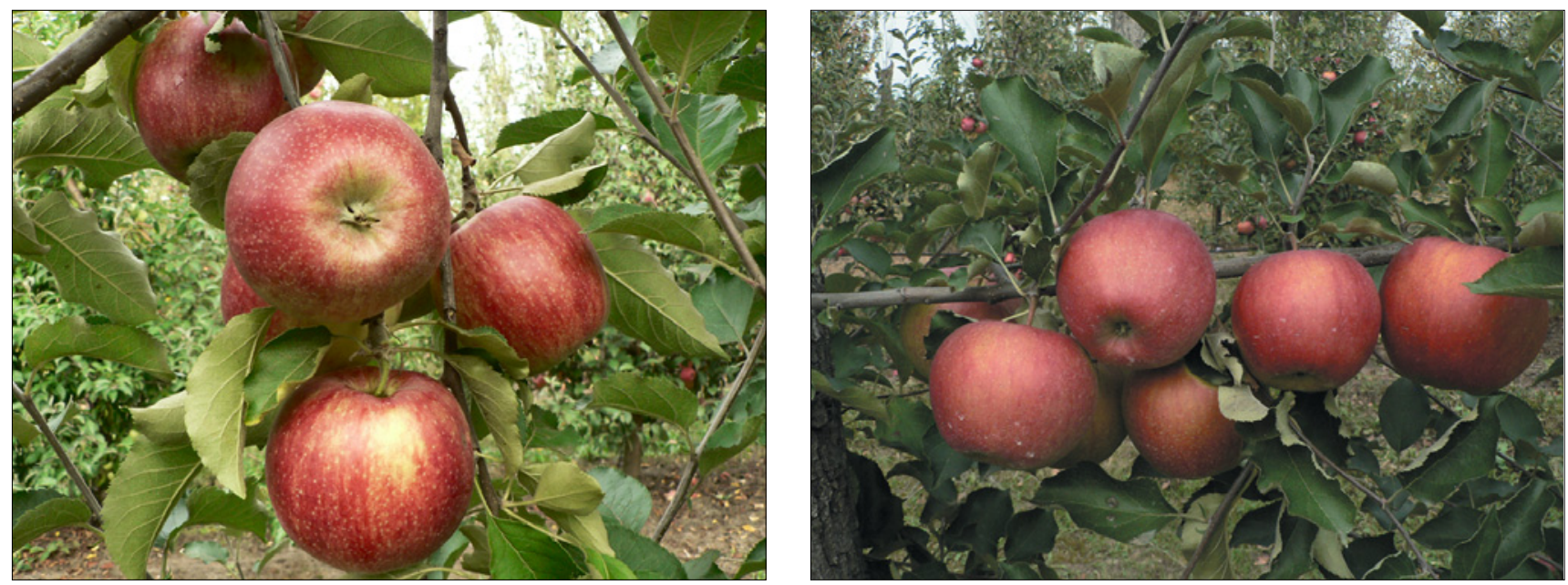

Fig. 3. Intensive apple skin color in clones DP-17 and DP-18 (from left to right, 2015)

Fruits of Ukrainian clones differed in pulp density: in DP-20 and DP-2, the pulp is dense both in the state of harvesting maturity $\left(9.5\right.$ and $\left.8.9 \mathrm{~kg} / \mathrm{cm}^{2}\right)$ and in the period of commercial maturity $\left(5.4\right.$ and $\left.4.6 \mathrm{~kg} / \mathrm{cm}^{2}\right)$. For 'Jonagold' fruits, this indicator was 8.1 and $4.1 \mathrm{~kg} / \mathrm{cm}^{2}$, respectively. The lowest density of pulp was found for DP-6 $\left(7.6 \mathrm{~kg} / \mathrm{cm}^{2}\right.$ harvesting maturity) and DP-15 and DP-8 $\left(3.8 \mathrm{~kg} / \mathrm{cm}^{2}\right.$ - commercial maturity).
In conditions of artificial cold (air temperature $2 \ldots 3{ }^{\circ} \mathrm{C}$, relative air humidity $85-90 \%$ ) clones DP-10, DP-18, DP-4, DP-6, DP-11, DP-14 and DP-15 which crop was formed in the years with sufficient precipitation and high air temperatures during the summer were distinguished by high keeping quality of fruit (187 $\pm 20-198 \pm 10$ days).

Determining the timing of the onset and duration of consumer ripeness and the keeping quality of fruits allowed dividing the studied 
clones into three groups according to the maturation period. DP-12, DP-13 were classified as the early winter group, DP-1, DP-2, DP-3, DP-5,
DP-7, DP-8, DP-16, DP-17, DP-19, DP-20 - as winter, and DP-4, DP-6, DP-9, DP-10, DP-11, DP-14, DP-15, DP-8 - as late winter group.

The economic efficiency of 'Jonagold' clones cultivation (2007 planting, $4.5 \times 1.5 \mathrm{~m}$, MM.106 rootstock), Podillia RSH of IH of the NAAS of Ukraine

\begin{tabular}{|l|c|c|c|c|c|c|c|c|}
\hline \multicolumn{1}{|c|}{ Indicators } & \multicolumn{7}{|c|}{ Variety, clone } \\
\cline { 2 - 10 } & $\begin{array}{c}\text { Idared } \\
\text { (c.) }\end{array}$ & $\begin{array}{c}\text { Jonagold } \\
\text { (c. c.) }\end{array}$ & DP-1 & DP-14 & DP-15 & DP-17 & DP-18 & DP-19 \\
\hline Yield, t/ha (average for 2014-2017) & 18.7 & 17.5 & 20.2 & 17.0 & 18.0 & 18.8 & 18.4 & 19.3 \\
Output of fruits of the highest, & & & & & & & & \\
I and II grades, t/ha & 12.7 & 12.6 & 15.8 & 12.2 & 14.9 & 16.2 & 13.4 & 16.0 \\
$\begin{array}{l}\text { Production costs per 1 ha of the garden, } \\
\text { thousand UAH }\end{array}$ & 51.34 & 53.10 & 53.94 & 52.94 & 53.26 & 53.51 & 53.38 & 53.66 \\
Sales price of 1 ton of fruit, thousand UAH & 7.80 & 8.44 & 8.97 & 8.34 & 8.96 & 9.72 & 8.96 & 9.31 \\
Revenue from the sale of fruits, thousand UAH/ha & 145.90 & 147.70 & 181.09 & 141.70 & 161.21 & 182.79 & 164.79 & 179.64 \\
Profit from 1 ha, thousand UAH & 94.56 & 94.60 & 127.15 & 88.76 & 107.95 & 129.28 & 111.41 & 125.98 \\
Cost of 1 ton of fruit, thousand UAH & 2.68 & 2.88 & 2.45 & 2.98 & 2.79 & 2.66 & 2.72 & 2.58 \\
Profitability level, \% & 184 & 178 & 235 & 168 & 203 & 242 & 209 & 235 \\
Payback period of capital investments, year & 3.2 & 3.2 & 2.9 & 2.2 & 3.0 & 2.9 & 3.0 & 2.9 \\
\hline
\end{tabular}

The highest economic efficiency of apple production was achieved when growing trees of DP-17 clone (Table 3). One hectare of 7 to 10-year plantations, with an annual average yield of $18.8 \mathrm{t} / \mathrm{ha}$, provided a profit of 129.28 thousand UAH, the level of profitability of apples production was $242 \%$ (Table 3). Plantations of spontaneous clones DP-4, DP-19, DP-1 also had a high level of profitability of apple production. In general, the cultivation of $60 \%$ of spontaneous clones provided $8-64 \%$ higher profitability of fruit production than the original variety. The shortest payback period of capital investments for planting is characteristic of the DP-14 clone due to its high early maturity.

\section{Conclusions}

Our studies have shown that the biological properties of plants of the Ukrainian 'Jonagold' clones correspond to the climatic conditions of the Western Forest-Steppe of Ukraine. According to the growth power of trees, clones DP-4, DP-5, DP-9, DP-10, DP-13, DP-14 and DP-17 belonged to the medium-sized group, for which a mixed type of fruiting is characteristic.

Clones DP-1, DP-3, DP-17, DP-18 and DP-19 were distinguished by a high yield of fruits of the highest and first grade. Clones DP-3, DP-8, DP-13, DP-14, DP-16, DP-17, DP-18 and DP-20 were recognized as the best according to the main indicators of fruit quality; the highest economic efficiency of apple production in the Western Forest-Steppe was provided by clones DP-14, DP-17, DP-18 and DP-19, which we recommend for introduction in this zone into plantations for the production of universal fruits.

\section{References}

1. Sedov, E. N. (2011). Selektciya i novye sorta yabloni [Selection and new varietyes of apple trees]. Orel: VNIISPK. [in Russian].

2. Kondratenko, T. Ye. (2010). Sorty yabluni dlia promyslovykh i amatorskykh sadiv Ukrainy [Apple varieties for industrial and amateur gardens of Ukraine]. Kyiv: Manuskrypt-ASV. [in Ukrainian].

3. Powell, A., Himelrick, D., \& Ebel, R. C. (2000). Apple varieties in Alabama. Alabama Coop. Ext. System., 7, 1-8. URL: https://ssl. acesag.auburn.edu/pubs/docs/A/ANR-1138/ANR-1138-archive.pdf

4. Tarnavska, K. P. (2015). Economic and Biological peculirities of the apple (Malus domestica Borkh.) cultivar Jonagold inlend clones. Sadivnytstvo [Horticulture], 69, 14-21. [in Ukrainian]

5. Kruczynska, D. (2008). Nowe odmiany jabloni. Warszawa: Hortpress Sp.z.o.o. [in Poland]

6. Shestopal, 0. M. (Ed.). (2006). Metodyka ekonomichnoi ta enerhetychnoi otsinky typiv nasadzhen, sortiv, investytsii v osnovnyi kapital, innovatsii ta rezultativ tekhnolohichnykh doslidzhen $u$ sadivnytstvi [Method of economic and energy estimation types of plantings, varieties, investments in fixed capital, innovations and results of technological research in gardening]. Kyiv: Institute of Agricultural Economics. [in Ukrainian]

7. Trohimchuk, A. I. (2013). The keeping quality of fruits of introduced varieties of apple trees grown in the conditions of the Forest-Steppe of Ukraine. In Sovremennye sorta i tehnologii dlya intensivnykh sadov: materialy Mezhdunarodnoy nauchno-prakticheskoy konferentsiii [Modern varieties and technologies for intensive gardens: materials of the Int. scientific-practical conf.] (pp. 249-251). June 15-18, 2013, Orel, Russia. [in Russian]

8. Ripamelnyk, V. P. (2002). Ahrobiolohichna otsinka perspektyvnoho sortymentu yabluni dlia Podillia Ukrainy [Economic and biological substantiation of perspective assortment of apple trees for Podollia region] (Cand. Agric. Sci. Diss.). Horticultural Institute NAAS, Vinnytsia, Ukraine. [in Ukrainian]

9. Mukhanin, I. V., \& Kuznetsova, T. A. (2019). Principles of forming an assortment of apple trees for trellis-dwarf gardens. Retrieved from http://asprus.ru/blog/principy-formirovaniya-sortimenta-yabloni-dlya-shpalerno-karlikovyx-sadov/ [in Russian]

10. Kviklys, D., Kvikliene, N., \& Uselis, N. (2013.) Suitability of 'Jonagold' apple clones for commercial growing in Lithuania. Proc. Latvian Acad. Sci., Section B., 67, 215-218. doi: 10.2478/ prolas-2013-0037 
11. Bogdanovich, T. V. (2017). Evaluation of the manufacturability of apple varieties for cultivation in orchards of intensive type. Plodovod. vinograd. Ûga Ross. [Fruit Growing and Viticulture of the South of Russia], 46, 1-8. [in Russian]

12. Honcharuk, Yu. D. (2014). The role of clonal selection of apple in the intensification of gardening. In Problemy i perspektivy razvitiya sovremennoy agrarnoy nauki: materialy Mezhdunarodnoy nauchno-prakticheskoy internet-konferentsii [Problems and prospects of development of modern agricultural science: materials of the Int. scientific and practical Internet Conf.] (pp. 36-37). June 1, 2014, Mykolaiv, Ukraine [in Ukrainian]

13. Volkodav, V. V. (Ed.). (2005). Metodyka derzhavnoho sortovyprobuvannia silskohospodarskykh kultur na prydatnist do poshyrennia v Ukraini (plodovi, yahidni, horikhoplidni, subtropichni, vynohrad ta shovkovytsia) [Methods of conducting expert examination of fruit and berry varieties, nuts and berries and grapes (fruit, berries, walnut, subtropical, grapes and mulberry)]. (Vol. 2, Part 2). Kyiv: Alefa. [in Ukrainian]

14. Sedova, E. N., \& Ogoltsova, T. P. (Eds.). (1999). Programma i metodika sortoizucheniya plodovikh, yagodnykh i orekhoplodnykh kul'tur [Program and method of sorting fruit, berry and nut tree crops]. Orel: VNYYSPK. [in Russian]

15. Yabluka. Nastanovy shchodo postachannia i kontroliuvannia yakosti: DSTU EIeK 00H FFV - 50:2007 [Apples. Supply and quality control guidelines: State Standart EEK 00H FFV - 50: 2007]. (2007). Kyiv: Derzhspozhyvstandart Ukrainy. [in Ukrainian]

16. Yabluka svizhi serednikh i piznikh terminiv dostyhannia. Tekhnichni umovy: HSTU 01.-37 - 160:2004 [Apples are a fresh medium to late maturity. Specifications. Industry standard of Ukraine 01.-37 - 160:2004]. (2005). Kyiv: Derzhspozhyvstandart Ukrainy. [in Ukrainian]

17. Dospekhov, B. A. (1985). Metodika polevogo opyta (s osnovami statisticheskoy obrabotki rezul'tatov issledovaniy) [Methods of field experiment (with the basics of statistical processing of research results)]. ( $5^{\text {nd }}$ ed., rev.). Moscow: Agropromizdat. [in Russian]

18. Kondratenko, P. V., \& Bublyk, M. 0. (1996). Metodyka provedennia doslidzhen z plodovymy kulturamy [Method of conducting researches with fruit crops]. Kyiv: Ahrarna nauka. [in Ukrainian]

19. Kondratenko, P. V. (2001). Adaptatsiia yabluni v Ukraini [Adaptation of apple in Ukraine]. Kyiv: Svit. [in Ukrainian]

20. Omelchenko, I. K. (2005). Kultura yabluni v Ukraini [Apple Culture in Ukraine]. ( $2^{\text {rd }}$ ed., rev.). Kyiv: Urozhai. [in Ukrainian]

21. Kruczynska, D. (2002). Nowe odmiany jabloni. Warszawa: Hortpress Sp.z.o.o. [in Poland]

\section{Використана література}

1. Седов Е. Н. Селекция и новые сорта яблони. Орел : ВНИИСпК, 2011. $624 \mathrm{c}$

2. Кондратенко Т. Є. Сорти яблуні для промислових і аматорських садів України. Київ : Манускрипт - АСВ, 2010. 400 с.

3. Powell A., Himelrick D., Ebel R. C. Apple varieties in Alabama. Alabama Coop. Ext. System. 2000. Vol. 7. P. 1-8. URL: https:// ssl.acesag.auburn.edu/pubs/docs/A/ANR-1138/ANR-1138archive.pdf

4. Тарнавська К. П. Господарсько-біологічні особливості клонів сорту яблуні (Malus domestica Borkh.) Джонаголд вітчизняної селекції. Садівництво. 2015. Вип. 69. С. 14-21.
5. Kruczynska D. Nowe odmiany jabloni. Warszawa : Hortpress Sp.z.o.o., 2008. 214 s.

6. Методика економічної та енергетичної оцінки типів насаджень, сортів, інвестицій в основний капітал, інновацій та результатів технологічних досліджень у садівництві / за ред. 0. М. Шестопаля. 2-ге вид. Київ : Інститут аграрної економіки, 2006. 141 с.

7. Трохимчук А. И. Лежкоспособность плодов интродуцированных сортов яблони, выращенных в условиях Лесостепи Украины. Современные сорта и технологии для интенсивных садов : матер. Междунар. науч.-практ. конф. (г. Орел, 15-18 июля 2013 г.). Орел, 2013. С. 249-251.

8. Ріпамельник В. П. Агробіологічна оцінка перспективного сортименту яблуні для Поділля України : дис. ... канд. С.-г. наук : спец. 06.01.07 «Плодівництво» / Уман. держ. аграр. акад. Умань, 2002. $210 \mathrm{c}$.

9. Муханин И. В., Кузнецова Т. А. Принципы формирования сортимента яблони для шпалерно-карликовых садов. 2019. URL: http://asprus.ru/blog/principy-formirovaniya-sortimentayabloni-dlya-shpalerno-karlikovyx-sadov/

10. Kviklys D., Kvikliene N., Uselis N. Suitability of 'Jonagold' apple clones for commercial growing in Lithuania. Proc. Latvian Acad. Sci., Section B. 2013. Vol. 67, Iss. 2. P. 215-218. doi: 10.2478/ prolas-2013-0037

11. Богданович Т. В. Оценка технологичности сортов яблони для возделывания в садах интенсивного типа. Плодоводство и виноградарство Юга России. 2017. № 46. С. 1-8.

12. Гончарук Ю. Д. Роль клонової селекції яблуні в інтенсифікації садівництва. Проблемы и перспективы развития современной аграрной науки : матер. Междунар. науч.-практ. интернет-конф. (г. Николаев, 1 июля 2014 г.). Николаев, 2014. С. 36-37.

13. Методика державного сортовипробування сільськогосподарських культур на придатність до поширення в Україні (плодові, ягідні, горіхоплідні, субтропічні, виноград та шовковиця) / за ред. В. В. Волкодава. Київ : Алефа, 2005. Вип. 2, Ч. 2. C. 161-232.

14. Программа и методика сортоизучения плодових, ягодных и орехоплодных культур / под ред. Е. Н. Седова, Т. П. Огольцовой. Орел : ВНИИСПК, 1999. 608 с.

15. Яблука. Настанови щодо постачання і контролювання якості : ДСТУ ЕЕК ООН FFV - 50:2007. [Чинний від 2007-12-24]. Київ : Держспоживстандарт України, 2007. 30 с. (Національний стандарт України)

16. Яблука свіжі середніх і пізніх термінів достигання. Технічні умови : ГСТУ 01.-37 - 160:2004 [Чинний від 2005-01-01]. Вид. офіц. Київ : Галузевий стандарт України, 2005. 11 с.

17. Доспехов Б. А. Методика полевого опыта (с основами статистической обработки результатов исследований). 5-е изд., доп. и перераб. Москва : Агропромиздат, 1985. 351 с.

18. Кондратенко П. В., Бублик М. О. Методика проведення досліджень з плодовими культурами. Київ : Аграрна наука, 1996. 96 с.

19. Кондратенко П. В. Адаптація яблуні в Україні. Київ : Світ, 2001. $191 \mathrm{c}$.

20. Омельченко І. К. Культура яблуні в Україні. 2-ге вид. Київ : Урожай, 2005. 304 с.

21. Kruczynska D. Nowe odmiany jabloni. Warszawa : Hortpress Sp.z.o.o., 2002. $198 \mathrm{~s}$. 


\section{УДК 634.11:631.526.32}

Кондратенко Т. . $^{1}$, Тарнавська К. П. ${ }^{2}$ Особливості росту, плодоношення та ефективність вирощування українських клонів яблуні (Malus domestica Borkh.) сорту 'Jonagold'. Plant Varieties Studying and Protection. 2019. T. 15, № 3. C. 219-229. https://doi.org/10.21498/2518-1017.15.3.2019.181080

${ }^{1}$ Національний університет біоресурсів і природокористування України, вул. Героїв Оборони, 15, м. Київ, 03041, Україна, e-mail: hortdep@gmail.com

${ }^{2}$ Подільська дослідна станція садівництва Інституту садівництва НААН України, вул. Наукова, 1, с. Медвеже Вушко, Вінницький р-н, Вінницька обл., 23226, Україна, e-mail: ktarn1235@ukr.net

Мета. На основі всебічного дослідження особливостей росту, розвитку, плодоношення та якості плодів рослин спонтанних мутантів яблуні (Malus domestica Borkh.) сорту 'Jonagold' виділити такі, що відрізняються від вихідного сорту за силою росту дерев та переважають за врожайністю, товарними якостями, лежкістю плодів та економічною ефективністю виробництва останніх. Методи. Польовий, лабораторний, порівняння, узагальнення та математичної статистики. Результати. Подано результати вивчення особливостей росту та плодоношення 20 українських спонтанних клонів сорту 'Jonagold' в умовах Західного Лісостепу України. Встановлено, що рослини досліджуваних клонів за строками початку і тривалістю основних фенологічних фаз і вегетаційного періоду не відрізнялись від більшості поширених і добре адаптованих до умов Поділля сортів яблуні. Знімальна стиглість плодів у клонів наставала у другій-третій декадах вересня, 3 різницею у сім діб. Дерева більшості клонів (ДП-4, ДП-5, ДП-9, ДП-10, ДП-13, ДП-14 і ДП-17) були середньорослими. Урожайність п'яти-восьмирічних насаджень клонів становить 12,1-32,3 т/га, що забезпечує економічно ефективне культивування в умовах Поділля, рівень рентабельності виробництва становить 66-242\%. Усі спонтанні мутанти формують плоди більші за середній розмір (крім ДП-20, великі), красиві, ошатні, які, залежно від клону, різняться за інтенсивністю та характером покривного забарвлення. Клони ДП-1, ДП-3, ДП-17, ДП-18 і ДП-19 відзначались найбільшим виходом яблук вищого та першого ґатунку і за цією властивістю значно перевищили контрольний сорт. Випробовувані клони поділено на три групи за строками достигання плодів: ранньозимові, зимові, пізньозимові. Висновки. Багаторічне оцінювання об'єктів дослідження дозволило встановити, що біологічні властивості рослин українських клонів сорту 'Jonagold' відповідають кліматичним умовам Західного Лісостепу України. За силою росту дерев більшість із них належать до групи середньорослих (ДП-4, ДП-5, ДП-9, ДП-10, ДП-13, ДП-14 і ДП-17) і характеризуються мішаним типом плодоношення. Клони ДП-1, ДП-3, ДП-17, ДП-18 і ДП-19 виділяються високим виходом плодів вищого та першого ґатунку. За основними показниками якості плодів кращими визнано клони ДП-3, ДП-8, ДП-13, ДП-14, ДП-16, ДП-17, ДП-18 і ДП-20; найвищу економічну ефективність виробництва яблук на Поділлі забезпечують клони ДП-14, ДП-17, ДП-18 і ДП-19. Останні рекомендовано для реєстрації у Державному реєстрі сортів рослин, як перспективні для впровадження у насадження з виробництва плодів універсального призначення у зоні Західного Лісостепу України.

Ключові слова: яблуня; copm; 'Jonagold'; клон; сила росту дерев; тип плодоношення; якість плодів; лежкість.

\section{УДК 634.11:631.526.32}

Кондратенко Т. Е. ${ }^{1}$, Тарнавская К. П. ${ }^{2}$ 0собенности роста, плодоношения и эффективность выращивания украинских клонов яблони (Malus domestica Borkh.) сорта 'Jonagold' // Plant Varieties Studying and Protection. 2019. T. 15, № 3. C. 219-229. https://doi.org/10.21498/2518-1017.15.3.2019.181080

${ }^{1}$ Национальный университет биоресурсов и природопользования Украины, ул. Героев Обороны, 15, г. Киев, 03041, Украина, e-mail: hortdep@gmail.com

${ }^{2}$ Подольская опытная станция садоводства Института садоводства НААН Украины, ул. Научная, 1, с. Медвежье Ушко, Винницкий p-н, Винницкая обл., 23226, Украина, e-mail: ktarn1235@ukr.net

Цель. По результатам всестороннего исследования особенностей роста, развития, плодоношения и качества плодов растений спонтанных мутантов яблони (Malus domestica Borkh.) сорта 'Jonagold' выделить отличающиеся от исходного сорта по силе роста деревьев, превосходящие по урожайности, товарным качествам, лежкости плодов и экономической эффективности производства последних. Методы. Полевой, лабораторный, сравнения, обобщения и математической статистики. Результаты. Представлены результаты изучения особенностей роста и плодоношения 20 украинских спонтанных клонов сорта 'Jonagold' в условиях Западной Лесостепи Украины. Определено, что растения исследуемых клонов по срокам начала и продолжительности основных фенологических фаз и вегетационного периода не отличались от большинства распространенных и хорошо адаптированных к условиям Подолья сортов яблони. Съемная зрелость плодов у клонов наступала во второй-третьей декадах сентября, с разницей в семь суток. Деревья большинства клонов (ДП-4, ДП-5, ДП-9, ДП-10, ДП-13, ДП-14 и ДП-17) были среднерослыми. Урожайность пяти-восьмилетних насаждений клонов составляла 12,1-32,3 т/га, что обеспечивало экономически эффективное культивирование в условиях Подолья, уровень рентабельности производства составлял 66-242\%. Все спонтанные мутанты формировали плоды выше среднего размера (кроме ДП-20, большие), красивые, нарядные, которые, в зависимости от клона, различались по интенсивности и характеру покровной окраски. Клоны ДП-1, ДП-3, ДП-17, ДП-18 и ДП-19 отличались самым большим выходом яблок высшего и первого товарного сорта и по этому свойству значительно превосходили контрольный сорт. Испытанные клоны разделены на три группы по срокам созревания плодов: раннезимние, зимние, позднезимние. Выводы. Многолетняя оценка объектов исследования позволила установить, что биологические свойства растений украинских клонов сорта 'Jonagold' соответствуют климатическим условиям Западной Лесостепи Украины. По силе роста деревьев большинство из них относятся к группе среднерослых (ДП-4, ДП-5, ДП-9, ДП-10, ДП-13, 
ДП-14 и ДП-17) и характеризовались смешанным типом плодоношения. Клоны ДП-1, ДП-3, ДП-17, ДП-18 и ДП-19 выделялись высоким выходом плодов высшего и первого товарного сортов. По основным показателям качества плодов лучшими признаны клоны ДП-3, ДП-8, ДП-13, ДП-14, ДП-16, ДП-17, ДП-18 и ДП-20; наиболее высокую экономическую эффективность производства яблок на Подолье обеспечивали клоны ДП-14, ДП-17, ДП-18 и
ДП-19. Последние рекомендованы для регистрации в Государственном реестре сортов растений, пригодных для выращивания в Украине, как перспективные для внедрения в насаждения по производству плодов универсального назначения в зоне Западной Лесостепи Украины.

Ключевые слова: яблоня; copm; 'Jonagold'; клон; сила роста деревьев; тип плодоношения; качество плодов; лежкость.

Надійшла / Received 19.07.2019

Погоджено до друку / Accepted 04.09.2019 